\title{
Prunus geminivirus A: A Novel Grablovirus Infecting Prunus spp.
}

Maher Al Rwahnih, ${ }^{\dagger}$ Department of Plant Pathology, University of California, Davis, 95616; Olufemi J. Alabi, Department of Plant Pathology \& Microbiology, Texas A\&M AgriLife Research and Extension Center, Weslaco 78596; and Nathaniel M. Westrick and Deborah Golino, Department of Plant Pathology, University of California, Davis

\begin{abstract}
Increased use of metagenomics for routine virus diagnosis has led to the characterization of several genus level geminiviruses from tree fruit long thought to exclusively host RNA viruses. In this study, the identification and molecular characterization of a novel geminivirus is reported for the first time in Prunus spp. The virus, provisionally named Prunus geminivirus A (PrGVA), was identified by Illumina sequencing from an asymptomatic plum tree. PrGVA was subsequently confirmed by rolling cycle amplification, cloning, and Sanger sequencing of its complete genome $(3,174$ to 3,176 nucleotides) from an additional 18 ( 9 apricot and 9 plum) field isolates. Apart from the nonanucleotide motif TAATATT $\downarrow$ AC present in its

virion strand origin of replication, other conserved motifs of PrGVA support its geminiviral origin. PrGVA shared highest complete genome (73 to 74\%), coat protein amino acid (83 to $85 \%$ ) and rep-associated amino acid (74\%) identities with Grapevine red blotch virus (GRBV). PrGVA was graft but not mechanically transmissible. Quantitative polymerase chain reaction screening of Prunus spp. in the National Clonal Germplasm Repository collection using newly designed primers and probes revealed 69.4\% (apricot), $55.8 \%$ (plum), and $8.3 \%$ (cherry) incidences of PrGVA. PrGVA is proposed as a novel member of the genus Grablovirus based on its close genome and phylogenetic relationship with GRBV.
\end{abstract}

The Geminiviridae family is characterized by viruses with small, circular, single-stranded, nonenveloped, mono- or bipartite DNA genomes (Brown et al. 2015). Until the last decade, the family consisted of members belonging to four genera that are largely typified by their insect vector. These are the leafhopper-transmitted members of genera Mastrevirus and Curtovirus, whitefly-transmitted members of genus Begomovirus, and the treehopper-transmitted members of genus Topocuvirus (Brown et al. 2015). Subsequently, diverse geminiviruses belonging to three other genera (Becurtovirus, Turncurtovirus, and Eragrovirus) were discovered, bringing the number of genera in the Geminiviridae family to seven. A common feature of viruses belonging to these seven genera is that they are primarily pathogens of economically important herbaceous hosts and weed species occurring mainly in the tropical and subtropical regions of the world. The situation changed over the last decade when several new geminiviruses were characterized from temperate and tropical woody plant species and additional herbaceous plants. These include Citrus chlorotic dwarf-associated virus (CCDaV) (Loconsole et al. 2012), French bean severe leaf curl virus (FbSLCV) (JX094280), Grapevine red blotch virus (GRBV) (Al Rwahnih et al. 2013; Krenz et al. 2012; Poojari et al. 2013), Euphorbia caput-medusae latent virus (EcmLV) (Bernardo et al. 2013), Jatropha mosaic virus (JaMV) (Polston et al. 2014), Alfalfa leaf curl virus (ALCV) (Bernardo et al. 2016; Roumagnac et al. 2015), Mulberry mosaic dwarfassociated virus (MMDaV) (Ma et al. 2015), Apple geminivirus (AGmV) (Liang et al. 2015), Plantago lanceolata latent virus (PILV) (Susi et al. 2017), and Grapevine geminivirus A (GGVA) (Al Rwahnih et al. 2017). These recent discoveries have led to a revisit of the Geminiviridae taxonomy, resulting in the establishment of two additional genera, Capulavirus and Grablovirus (Adams et al. 2017). The genus Capulavirus consist of ALCV, EcmLV, FbSLCV, and PILV while GRBV is the only member of the genus Grablovirus. Two other unclassified genera, consisting of $\mathrm{CCDaV}$ and $\mathrm{MMDaV}$ on the one hand and AGmV and GGVA on the other, await

${ }^{\dagger}$ Corresponding author: M. Al Rwahnih; E-mail: malrwahnih@ucdavis.edu

*The $\boldsymbol{e}$-Xtra logo stands for "electronic extra" and indicates that four supplementary figures are published online.

Accepted for publication 18 December 2017.

() 2018 The American Phytopathological Society recognition by the International Committee on Taxonomy of Viruses (ICTV) due to lack of information on their vectors or ability to form geminate particles characteristic of the family (Varsani et al. 2017).

To date, the genus Grablovirus consists of GRBV isolates from Canada, South Korea, and the United States. Because the Grablovirus genus has no additional related viruses, a genome-wide species demarcation threshold of $<80 \%$ was proposed for members of the genus pending reports of new grabloviruses (Varsani et al. 2017). The discovery of a novel putative Grablovirus, provisionally named Prunus geminivirus A (PrGVA), is reported in this study. PrGVA has genome organization similar to that of GRBV and also shares very close phylogenic relationship with GRBV based on analysis of complete genome, coat protein (CP) amino acid, and replicase (Rep) amino acid sequences. However, at 73.3 and $74.4 \%$ identities with GRBV isolates 3138-03 and NY137, respectively, its complete genome fell short of the current Grablovirus species demarcation threshold proposed by Varsani et al. (2017). These results, together with the discovery of yet another distantly related putative Grablovirus, Wild vitis virus 1 (WVV1), from a wild grapevine species in California (Perry et al. 2018), opens avenues for a revisit of the species demarcation criteria of the new genus.

\section{Materials and Methods}

Plant material. In 2013, a domestic plum variety, named FT7, grafted onto Marianna 2624 rootstock was received for inclusion in the Foundation Plant Services (FPS, University of California Davis) collection. The tree was grown in a screenhouse and assayed for known fruit tree pathogens, as described below.

Assays for known fruit tree pathogens. Total nucleic acid (TNA) was isolated from FT7 as described by Al Rwahnih et al. (2017). The TNA sample was analyzed by reverse-transcription quantitative polymerase chain reaction (RT-qPCR) for a panel of 15 Prunusinfecting viruses belonging to six genera and two viroid species. The RT-qPCR assays were performed using TaqMan probes on the QuantStudio 6 Flex Real-Time PCR System (ThermoFisher Scientific, Carlsbad, CA) as described previously (Osman et al. 2012) (V. Klaassen and M. Al Rwahnih, unpublished data). The targeted pathogens included Little cherry virus 1 (genus Velarivirus); Little cherry virus 2 and Plum bark necrosis stem pitting-associated virus (genus Ampelovirus); Apple chlorotic leaf spot virus (genus Trichovirus); Apple mosaic virus, American plum line pattern virus, Prune dwarf virus, and Prunus necrotic ringspot virus in the genus Ilarvirus; Cherry green ring mottle virus (genus Foveavirus); Cherry leaf roll virus, Peach rosette mosaic virus, and Tomato ringspot virus in the genus Nepovirus; 
Cherry necrotic rusty mottle virus (genus Robigovirus); Cherry rasp leaf virus (genus Cheravirus); Cherry virus A (genus Capillovirus); Hop stunt viroid (genus Hostuviroid); and Peach latent mosaic viroid (genus Pelamoviroid). FT7 was also screened using a universal phytoplasma assay (Hodgetts et al. 2009). Positive, negative, and no-template control samples were included for each pathogen assay.

Biological assays. As part of the FPS pipeline for routine testing of new germplasm introductions, several bioassays were performed on FT7. Bud chips from FT7 were grafted onto stone fruit indicator cultivars, including Elberta (peach), Tilton (apricot), Shiro (plum), Bing (cherry), Kwanzan (cherry), and Tomentosa (cherry), as previously described (Jelkmann 2004). Graft inoculation assays were performed during fall 2013 and the experimental trees were observed for presence of virus-like symptoms during fall and spring of two consecutive years. In addition, leaf petiole tissue from the FT7 tree was mechanically inoculated onto a panel of herbaceous indicator plants, including Chenopodium amaranticolor, C. quinoa, Cucumis sativus, and Nicotiana clevelandii, as previously described (Rowhani et al. 2005).

In 2017, bud chips from FT7 were grafted onto 12 GF305 peach seedlings, 4 Myrobalan 29C, and 4 Citation plum rootstocks. The grafted plants were maintained in the greenhouse. Mechanical inoculation of material from FT7 onto a panel of herbaceous was also repeated as described above.

High-throughput sequencing and sequence analysis. A TNA aliquot from FT7 was subjected to ribosomal RNA depletion and a cDNA library was constructed from the RNA template using a TruSeq Stranded Total RNA with Ribo-Zero Plant kit (Illumina, San Diego, CA). Sequencing was performed in-house on the Illumina NextSeq 500 platform and the raw high-throughput sequencing (HTS) reads were trimmed using the CLC Bio Genomic Workstation (v8.5.1; Qiagen, Hilden, Germany) trimming tool. Library construction, sequencing, sequence assembly, and analyses were performed using tools, programs, and conditions described by Al Rwahnih et al. (2017).

HTS validation and determination of geminiviral genome sequences. A TNA aliquot from FT7 was enriched for geminivirus genome targets via rolling cycle amplification (RCA) (Inoue-Nagata et al. 2004) using a TempliPhi Amplification Kit (GE Healthcare Life Sciences, Uppsala, Sweden), as described in the manufacturer's protocol. Two pairs of abutting primers (Table 1) were designed based on the HTS-derived geminiviral sequence obtained from FT7 and used in conventional PCR with RCA or TNA aliquots as template to drive the amplification of circular single-stranded (ss)DNA genomic DNA fragment present in the sample. The PCR were carried out in $25-\mu 1$ reaction volumes using the PrimeSTAR GXL DNA Polymerase (Clontech Laboratories, Inc., Palo Alto, CA), according to the manufacturer's rapid protocol recommendations. Obtained DNA amplicons (Fig. 1) were gel eluted with the Zymoclean Gel DNA Recovery Kit (Zymo Research Corporation, Irvine, CA), A-tailed, cloned into pCR2.1 TOPO-TA vector (ThermoFischer Scientific), and Sanger sequenced as two overlapping DNA fragments in a commercial facility.
Genome and phylogenetic analysis. Blastn analysis was performed for the assembled complete viral ssDNA genome sequence to ascertain its viral origin and to identify sequences producing significant alignments to isolate FT7. The search for potential proteinencoding segments in the complete genome sequence was conducted using the program ORF Finder and translation products of each predicted open reading frame (ORF) were verified using the SMART BLAST algorithm (https://www.ncbi.nlm.nih.gov/orffinder/). The program FGENESH+ v.2.6 (Solovyev 2007) was used to predict the $\mathrm{C} 1$ : $\mathrm{C} 2$ fusion protein based on similarity with its geminivirus homologs (http://www.softberry.com/berry.phtml?topic=fgenes_plus\& group=programs\&subgroup=gfs). For this purpose, the complete genome of the new virus was queried separately with the $\mathrm{C} 1: \mathrm{C} 2$ protein sequences of GRBV isolate NY137 and an isolate of Chickpea chlorosis virus- $B$. The predicted protein was considered acceptable if both independent queries yielded the same amino acid sequences. Multiple sequence alignments were performed for complete genome and genespecific nucleotide and protein sequences of the virus and other geminiviruses using the MUSCLE alignment program (https://www.ebi. ac.uk/Tools $/ \mathrm{msa} / \mathrm{muscle} /$ ). The alignment files were used to generate sequence identity matrices using the SDT v.1.2 program (Muhire et al. 2014) and for phylogenetic analysis using the MEGA v.7.0 program (Kumar et al. 2016). Sequences of representative members of all nine recognized and two unclassified genera in the family Geminivir$i d a e$ were included in these analyses. The genome architecture of the new virus was drawn using the SnapGene Viewer 4.0.2 software (GSL Biotech; http://www.snapgene.com/) and its CP-encoded nuclear localization signal (NLS) motif was predicted using the program NucPred (Brameier et al. 2007). The Rep protein N-terminal doublestranded (ds)RNA binding motifs of the new virus were identified based on homology with corresponding amino acid sequences of other members of the family Geminiviridae.

Development of conventional PCR and qPCR diagnostic assays. An alignment file of all the newly derived sequences (plum $=$ 9 and apricot $=9$ ) was used to design primers for routine detection of the novel virus in epidemiological studies by conventional PCR and qPCR (Table 1). The Primer Express software (v3.0.1; ThermoFisher Scientific, Grand Island, NY) was used for the design of primers and probe and the minimal criteria for the design of qPCR assays (Bustin et al. 2009) was followed in developing the qPCR assay. All qPCR probes were MGB probes, labeled with 5' FAM reporters and a nonfluorescent quencher. The amplification conditions for the conventional PCR assay consisted of one cycle of $94^{\circ} \mathrm{C}$ for $2 \mathrm{~min} ; 35 \mathrm{cy}$ cles of $94^{\circ} \mathrm{C}$ for $30 \mathrm{~s}, 56^{\circ} \mathrm{C}$ for $45 \mathrm{~s}$, and $72^{\circ} \mathrm{C}$ for $45 \mathrm{~s}$; and one cycle of $72^{\circ} \mathrm{C}$ for $5 \mathrm{~min}$. Cycling conditions for qPCR were $50^{\circ} \mathrm{C}$ for $2 \mathrm{~min}$ and $95^{\circ} \mathrm{C}$ for $20 \mathrm{~s}$, then 40 cycles at $95^{\circ} \mathrm{C}$ for $1 \mathrm{~s}$ and $60^{\circ} \mathrm{C}$ for $20 \mathrm{~s}$. Assay optimization and analysis of the qPCR data were conducted as previously described (Al Rwahnih et al. 2017). The virus specificities of DNA amplicons obtained in conventional PCR and qPCR assays were verified via direct sequencing of gel-eluted DNA fragments of

Table 1. Primers and probes designed in this study for the molecular characterization and routine diagnosis of Prunus geminivirus A (PrGVA) ${ }^{\mathrm{a}}$

\begin{tabular}{lllcc}
\hline Primer name $^{\mathbf{b}}$ & Genomic region $^{\mathbf{c}}$ & \multicolumn{1}{c}{ Sequence $\left(\mathbf{5}^{\prime} \mathbf{-} \mathbf{3}^{\prime}\right)^{\mathbf{d}}$} & Temperature $\left({ }^{\circ} \mathbf{C}\right)$ & Amplicon size $(\mathbf{b p})$ \\
\hline PrGVAv157 & LIR & CgATTggACAgAggTACTTACAgT & 56 & 3,175 \\
PrGVAc165 & LIR & gTCCAATCgCAgAACTCCATAC & $\ldots$ & $\ldots$ \\
PrGVAv1679 & V3 & ggTCAACATAgACCAgACAgTCgT & 56 & $\ldots$ \\
PrGVAc1682 & V3 & gACCAgAACCAAgTTCTAAgTCC & $\ldots$ & $\ldots$ \\
PrGVAv2527 & C1 & TTggTTAgCAAAgTATTCAAgTCg & 56 & $\ldots$ \\
PrGVAc165 & LIR & gTCCAATCgCAgAACTCCATAC & $\ldots$ & $\ldots$ \\
PrGVAv1514 & V3 & ACgTTgAAgAgACgTCgTTCTg & 60 & $\ldots$ \\
PrGVAc1596 & V3 & TCTTCATCAggATCAACCATCACT & $\ldots$ & $\ldots$ \\
Probev1552 & V3 & TTCCAACTTgAAgCgAAg & $\ldots$ & $\ldots$ \\
\hline
\end{tabular}

${ }^{a}$ Additional primer-walking primers (data not shown) were designed to complete the virus genome based on sequences fragments generated with the abutting primers.

${ }^{\mathrm{b}}$ Primer orientation $(\mathrm{v}=$ virion-sense and $\mathrm{c}=$ complementary-sense $)$ and locations of their first nucleotides on virus genome are indicated.

${ }^{\mathrm{c}} \mathrm{LIR}=$ large intergenic region, $\mathrm{C} 1=\mathrm{C} 1$ protein, and $\mathrm{V} 3=\mathrm{V} 3$ protein.

${ }^{\mathrm{d}}$ Underlined nucleotides indicate sequence overlaps between the pair of abutting primers used for amplification of complete genome of PrGVA. 
representative samples at the UC Davis sequencing facility (http://dnaseq.ucdavis.edu).

Determination of virus incidence. A survey was conducted to determine the incidence of the newly characterized virus in the Prunus spp. collection of the National Clonal Germplasm Repository (NCGR) at Winters, CA. The survey was carried out during spring 2017 and leaf petiole samples were collected from 215 trees. Selected trees represented a diverse array of Prunus spp. (peach $=58$, cherry $=$ 36 , apricot $=49$, plum $=52$, and almond $=20$ ) sourced originally from worldwide geographical regions, several of which have been previously surveyed and screened by Osman et al. (2012). Based on the test results, the complete ssDNA genome of the new virus was determined from additional nine plum and nine apricot samples using abutting primers (Table 1) and assays described above.

\section{Results}

Biological assays. No visible virus-like symptom was observed on the original FT7 source tree or the graft-inoculated indicators cultivars Elberta (peach), Tilton (apricot), Shiro (plum), Bing (cherry), Kwanzan (cherry), and Tomentosa (cherry) during the spring and fall seasons of 2014 and 2015. Also, none of the four mechanically inoculated herbaceous plants produced virus-like symptoms. Sample FT7 was advanced for HTS diagnosis in order to exclude the presence of unknown virus or virus-like agents in the sample and to rule out the presence of known viruses at concentrations undetectable with traditional assays.

A novel geminivirus identified in FT7 via HTS. Approximately 28 million reads (each 76 nucleotides [nt] in length) were recovered from the Illumina sequencing of FT7 cDNA library. The assembly of these reads yielded 42,037 contigs. The annotation and tblastx analyses of the contigs against the reference virus genomes in the $\mathrm{Na}$ tional Center for Biotechnology Information resulted in the identification of a single 3,175-nt contig (GenBank accession number MF579394) showing 76 to $78 \%$ homology with several GRBV isolates at 74 to $76 \%$ query coverage. A scan of this contig revealed the

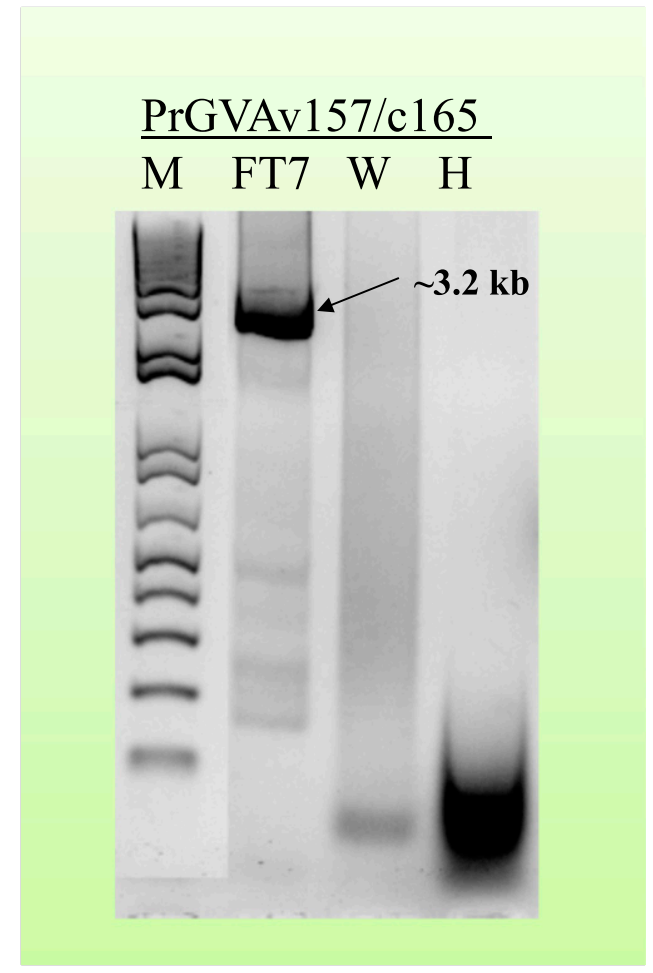

Fig. 1. Amplification of complete single-stranded DNA genome of Prunus geminivirus A (PrGVA) by conventional polymerase chain reaction from plum isolate FT7 using a pair of newly designed abutting primers, PrGVAv157 and PrGVAc165. Lane FT7 = originally infected plum tree, lane $\mathrm{W}=$ water, lane $\mathrm{H}=$ healthy control, and lane $M=1-k b$-plus ladder. presence of the nonanucleotide motif TAATATT $\downarrow$ AC and a blastx analysis produced significant alignments with several replicationassociated putative conserved domains of known geminiviruses (data not shown). These results indicated the presence of a novel geminivirus in sample FT7, for which the tentative name Prunus geminivirus A (PrGVA) is assigned.

Complete genome of PrGVA determined via PCR, cloning, and Sanger sequencing. The two pairs of newly designed abutting primers pairs (Table 1) each amplified approximately 3-kb DNA bands from FT7 (Fig. 1). Cloning and Sanger sequencing of each DNA fragment resulted in the assembly of complete genome of PrGVA of 3,175 bp (GenBank accession number MF504029). Complete genome sequences of PrGVA were similarly obtained from additional isolates from plum $(n=9)$ and apricot $(n=9)$ trees (Table 2$)$ with the primer pair PGVAv157 and PGVAc165 (Table 1). The length of these complete genome sequences ranged from 3,174 to 3,176 nt, with variations in genome length due to presence of indels in the large intergenic region (LIR) of some PrGVA isolates (GenBank accession numbers MF504030-40 and MF5104408-14). These results provide validation for the HTS data and revealed the occurrence of PrGVA in several apricot (Prunus armeniaca) and plum (Prunus spp.) trees in the NCGR collection.

PrGVA is graft but not mechanically transmissible. TNA prepared from petiole and bark scrapings of 20 graft-inoculated trees (GF305 peach seedlings $=12$, Myrobalan 29C $=4$, and Citation plum rootstocks $=4$ ) were screened by qPCR 3 and 6 months postinoculation using primers and conditions described above (Table 1). Mechanically inoculated herbaceous host plants were similarly tested 3 weeks postinoculation. PrGVA was detected in petiole and bark scrapings of only one GF305 peach (P. persica) rootstock at 6 months post graft inoculation. The presence of PrGVA in this rootstock material was confirmed through multiple repeated tests. All nongrafted GF305 seedlings and healthy grafted controls tested negative for PrGVA. Furthermore, the complete genome of PrGVA was amplified from the infected GF305 material using the primers PGVAv157 and PGVAc165 (Table 1). Analysis of the Sanger-sequenced isolate of PrGVA from GF305 (GenBank accession number MF579393)

Table 2. GenBank accession numbers of complete genome sequences of Prunus geminivirus A (PrGVA) isolates derived in this study

\begin{tabular}{|c|c|c|c|c|}
\hline $\begin{array}{l}\text { Source, } \\
\text { crop, isolate }\end{array}$ & Species & Variety & Country & Accession \\
\hline \multicolumn{5}{|l|}{ USDA } \\
\hline \multicolumn{5}{|l|}{$\mathrm{NCGR}^{\mathrm{a}}$} \\
\hline \multicolumn{5}{|l|}{ Apricot } \\
\hline AP4 & $\begin{array}{l}\text { Prunus } \\
\text { armeniaca }\end{array}$ & No. 279/II-3 & Poland & MF504030 \\
\hline AP6 & P. armeniaca & Almon & Pakistan & MF504031 \\
\hline AP9 & P. armeniaca & Palsteyn & South Africa & MF504032 \\
\hline AP10 & P. armeniaca & Nonno & Italy & MF504033 \\
\hline AP11 & P. armeniaca & Luizet & France & MF504034 \\
\hline AP12 & P. armeniaca & KAZ 95 17-07 & Kazakhstan & MF504035 \\
\hline AP13 & P. armeniaca & Rakovsky BU 33 & Hungary & MF504036 \\
\hline AP14 & P. armeniaca & $\begin{array}{l}\text { Santa Clara } \\
\text { Sweet }\end{array}$ & United States & MF504037 \\
\hline AP16 & P. armeniaca & DPRU 1787 & Turkey & MF504038 \\
\hline \multicolumn{5}{|l|}{ Plum } \\
\hline PL1 & Prunus spp. & Botanky & India & MF504039 \\
\hline PL2 & P. simonii & Simon & China & MF504040 \\
\hline PL4 & P. salicina & Formosa & United States & MF510408 \\
\hline PL6 & P. domestica & $\begin{array}{l}\text { Reine Claude de } \\
\text { Bavay }\end{array}$ & Unknown & MF510409 \\
\hline PL8 & P. domestica & Pervenec 36-23 & USSR & MF510410 \\
\hline PL9 & P. domestica & Purple Gage & Unknown & MF510411 \\
\hline PL10 & P. salicina & Wickson & Unknown & MF510412 \\
\hline PL11 & P. salicina & QLG 087 & China & MF510413 \\
\hline PL13 & P. salicina & Abundance & United States & MF510414 \\
\hline
\end{tabular}

${ }^{a}$ United States Department of Agriculture National Clonal Germplasm Repository. 
revealed 97 to $99 \%$ complete genome identities with virus isolates from plum and apricot. The results showed that PrGVA is graft transmissible, albeit at low frequency. All mechanically inoculated herbaceous plants tested negative for PrGVA.

Genome organization and molecular properties of PrGVA. Like most geminiviruses, PrGVA possesses the nonanucleotide motif TAATATT $\downarrow$ AC in its virion strand origin of replication (Fig. 2). Three virion-sense (V1, V2, and V3) and three complementarysense $(\mathrm{C} 1, \mathrm{C} 2$, and $\mathrm{C} 3)$ putative translation products were identified in the circular ssDNA genome of PrGVA (Fig. 2). In addition, a C1: $\mathrm{C} 2$ fusion protein that is potentially expressed from spliced $\mathrm{C} 1$ and C2 transcripts of PrGVA is predicted using the FGENESH+ 2.6 (http://www.softberry.com/berry.phtml?topic=fgenes_plus\&group= programs\&subgroup=gfs) program. This $38.3-\mathrm{kDa} \mathrm{C} 1: \mathrm{C} 2 \mathrm{rep}-$ associated fusion protein spans nucleotide positions 1,877 to 2,264 and 2,428 to 3,017 of isolate FT7 (Fig. 2). The virion-sense and complementary-sense genes are separated by a 415-nt LIR encompassing the virion strand origin of replication and a short intergenic region that is $159 \mathrm{nt}$ in length. The CP-encoded NLS of PrGVA was predicted to be "KRRPSRRYRRATKKRSGRSSQRKRRARPR" (NucPred score $=0.68$; Supplementary Fig. S1). The N-terminal repassociated protein sequences of PrGVA also contains the dsRNAbinding motifs FLTYP (motif I), HLH (motif II), and YVSKD (motif III) together with the so-called GRS domain (Supplementary Fig. S2) (Nash et al. 2011). In this respect, the dsRNA-binding motifs and GRS domain of PrGVA most resemble those of GRBV and WVV1 compared with other species in the family Geminiviridae.

PrGVA is a putative Grablovirus sp. In pairwise comparisons, PrGVA was most (73 to 74\%) identical to GRBV isolates on a whole-genome basis. The virus also shared $69 \%$ complete genome identities with WVV1, another recently characterized putative grablovirus from noncultivated Vitis spp. sampled from California (Perry et al. 2018). Interestingly, WVV1 shared 68\% complete genome identity with GRBV isolates, indicating that PrGVA and GRBV are more identical to each other than either is to WVV1 (Table 3). Analysis of gene-specific nucleotide and amino acid

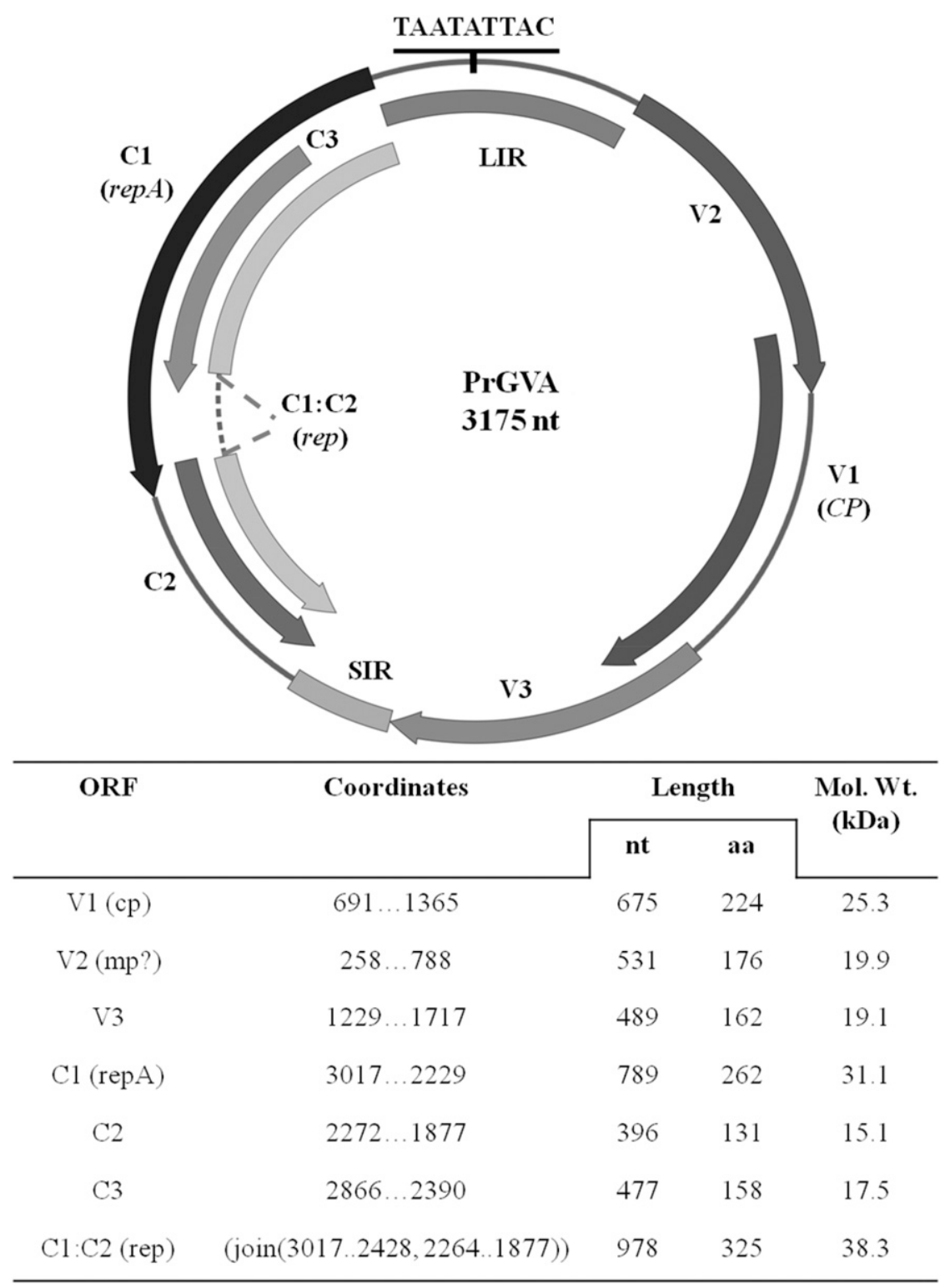

Fig. 2. Genome map of the circular single-stranded DNA molecule of Prunus geminivirus $A$ (PrGVA). Arrows denote the virion-sense $(\mathrm{V})$ and complementary-sense $(\mathrm{C})$ geminiviral genes encoded by the virus. LIR = long intergenic region sequences, $\mathrm{SIR}=$ short intergenic region sequences, $\mathrm{V} 1=$ coat protein, $\mathrm{V} 2=$ precoat protein, $\mathrm{V} 3=$ open reading frame V3, C1 = repA protein, C2 = transcriptional activator protein, C3 = replication enhancer protein, and C1:C2 = rep-associated protein. The stem-loop in the LIR of PrGVA contains the conserved geminiviral nonanucleotide sequence "TAATATT $\downarrow A C$ " present in the virion strand origin of replication. The map is based on PrGVA isolate FT7 (GenBank accession number MF504029) 
sequences showed that PrGVA shared greater CP (76 to $77 \%$ nt and 83 to $85 \%$ amino acid [aa]) and Rep (75\% nt and $74 \%$ aa) gene identities with GRBV compared with WVV1 (70 nt and $78 \%$ aa CP and $70 \mathrm{nt}$ and $68 \%$ aa Rep identities) (Table 3). However, the predicted $\mathrm{C} 2$ and $\mathrm{C} 3$ cistrons of PrGVA were more identical to corresponding sequences of WVV1 than to GRBV (Table 3). As shown in the colorcoded sequence identity matrix (Supplementary Fig. S3) and the derived phylogenetic trees (Fig. 3), PrGVA isolates clustered in the Grablovirus clade along with GRBV and WVV1 isolates based on complete genome (Fig. 3A) as well as CP (Fig. 3B) and Rep (Fig. 3C) amino acid sequences. In this clade, PrGVA isolates formed a distinct subclade closer to the GRBV subclade and distant from the subclade formed by WVV1 (Fig. 3). These results provide strong support for the assignment of PrGVA into the genus Grablovirus and justifies a revisit of the current $<80 \%$ genome-wide pairwise identity species threshold (Varsani et al. 2017) in favor of a lower species demarcation cut-off value for the genus.

PrGVA is relatively widespread in the NCGR collection. A sensitive diagnostic qPCR assay was successfully developed for routine detection of PrGVA (Supplementary Fig. S4). The specificity of the assay was confirmed by Sanger sequencing of an amplified DNA fragment (data not shown). Using this assay, freshly collected samples from a total of 215 trees of diverse Prunus spp. (almond $=20$, apricot $=49$, cherry $=36$, peach $=58$, and plum $=52$ ) were screened for the presence of PrGVA. In all, $66(30.7 \%)$ of the tested trees (apricot $=34$ of 49 or $69.4 \%$, cherry $=3$ of 36 or $8.3 \%$, and plum $=29$ of 52 or $55.8 \%$ ) were positive for PrGVA (Table 4). All almond and peach trees tested negative for PrGVA (Table 4), indicating the absence of the virus in these plant species under natural field conditions. A breakdown of the 66 PrGVA-positive trees by origin indicated that they were originally introduced into the NCGR collection from 22 countries (Table 2), thus indicating a wide distribution of the novel Grablovirus sp. No visible virus symptoms were observed on the positive trees.

\section{Discussion}

The recovery of PrGVA in FT7 further underscores the benefits of HTS as a versatile tool for the culture-independent detection

Table 3. Complete genome and gene-specific nucleotide (nt) and amino acid (aa) sequence comparisons among one definitive and two putative Grablovirus species

\begin{tabular}{|c|c|c|c|}
\hline Region (nt/aa) & Grablovirus $^{\text {a }}$ & Length (nt/aa) & ID (nt/aa) (\%) \\
\hline \multirow[t]{3}{*}{ Genome } & PrGVA & 3,175 & \\
\hline & GRBV & 3,206 & $73-74$ \\
\hline & WVV1 & 3,237 & 69 \\
\hline \multirow[t]{3}{*}{ V2 } & PrGVA & $531 / 176$ & \\
\hline & GRBV & $522 / 171$ & $60-62 / 47$ \\
\hline & WVV1 & $564 / 187$ & $48 / 39$ \\
\hline \multirow[t]{3}{*}{$\mathrm{V} 1 / \mathrm{CP}$} & PrGVA & $675 / 224$ & \\
\hline & GRBV & $678 / 225$ & $76-77 / 83-85$ \\
\hline & WVV1 & $672 / 223$ & $70 / 78$ \\
\hline \multirow[t]{3}{*}{ V3 } & PrGVA & $489 / 162$ & \\
\hline & GRBV & $375 / 124$ & $58-59 / 49$ \\
\hline & WVV1 & $372 / 123$ & $44 / 34$ \\
\hline \multirow[t]{3}{*}{$\mathrm{C} 3$} & PrGVA & $477 / 158$ & \\
\hline & GRBV & $480 / 159$ & $36-38 / 9-12$ \\
\hline & WVV1 & $465 / 154$ & $73 / 59$ \\
\hline \multirow[t]{3}{*}{$\mathrm{C} 1$} & PrGVA & $789 / 262$ & \\
\hline & GRBV & $786 / 261$ & $72-74 / 63$ \\
\hline & WVV1 & $795 / 264$ & $68 / 58$ \\
\hline \multirow[t]{3}{*}{$\mathrm{C} 2$} & PrGVA & $396 / 131$ & \\
\hline & GRBV & $450 / 149$ & $33-35 / 8-9$ \\
\hline & WVV1 & $483 / 160$ & $60 / 64$ \\
\hline \multirow[t]{3}{*}{$\mathrm{C} 1: \mathrm{C} 2$} & PrGVA & $978 / 325$ & \\
\hline & GRBV & $975 / 324$ & $75 / 74$ \\
\hline & WVV1 & $984 / 327$ & $70 / 68$ \\
\hline
\end{tabular}

a PrGVA = prunus geminivirus $\mathrm{A}, \mathrm{GRBV}=$ grapevine red blotch virus, and WVV1 = wild vitis virus 1 . of novel viruses that may have escaped traditional virus diagnostic techniques and may also be present as asymptomatic infections. As previously discussed (Al Rwahnih et al. 2017), this versatile tool enabled the discovery of the majority of geminiviruses characterized from woody perennials in recent years. Therefore, it seems inevitable that HTS will be adopted globally for certification purposes in plant certification programs in the coming years.

The discovery of PrGVA (this study) and WVV1 (Perry et al. 2018), and the assignment of both viruses into the genus Grablovi$r u s$, opens avenues to address pertinent questions with respect to the species demarcation criteria in this new genus and the origin and evolutionary history of GRBV, its type species. Since its first identification and characterization (Al Rwahnih et al. 2013; Krenz et al. 2012; Poojari et al. 2013), GRBV has garnered intense interest among the global community of grapevine virologists and the wider viticultural community due to its documented economic impacts (Ricketts et al. 2015). As a consequence, tremendous efforts and resources have been devoted to gaining a better understanding of its biology, molecular biology, and epidemiology. Among other significant breakthroughs, Koch's postulates were successfully demonstrated for GRBV (Fuchs et al. 2015), the virus was detected in a Vitis vinifera herbarium sample archived since 1940 (Al Rwahnih et al. 2015) and in free-living vines proximal to commercial vineyards (Bahder et al. 2016b; Perry et al. 2016), and the three-cornered alfalfa hopper (Spissistilus festinus (Say)) was identified as its bona fide vector (Bahder et al. 2016a). A combination of these layers of evidence coupled with the unique genome organization and distinct phylogeny of GRBV isolates prompted the establishment of a new Grablovirus genus in the family Geminiviridae (Varsani et al. 2017) and its subsequent ratification by the ICTV (Adams et al. 2017). Because GRBV is the type and only member of this new genus, Varsani et al. (2017) proposed a $<80 \%$ genome-wide pairwise identity as the species demarcation threshold for grabloviruses, pending when additional full genome sequences of related viruses are determined. The reliability of such a genome-wide pairwise-identity-based classification system is dependent upon the depth of available sequence data to rationally distinguish species and strains. Thus, the identification and characterization of WVV1 (Perry et al. 2018) and PrGVA (this study) provide opportunity for a better refinement of the Grablovirus taxonomy. Using the genome-wide pairwise-identity approach and recommended suite of programs (Muhire et al. 2013), a quick analysis of a total of 81 complete genome sequences of grabloviruses $(\mathrm{GRBV}=53, \mathrm{WVV} 1=9$, and PrGVA $=19$ ) resulted in a pairwise identity scores distribution with notable "peaks" at approximately 68 to 69,73 to 74 , and 92 to $100 \%$ and clear "valleys" at approximately 70 to 72 and 75 to $91 \%$ (Fig. 4). Taking into consideration the assertion that placing the species demarcation threshold within one of the valleys would yield a classification scheme with minimal conflicts whereas placing it at one of the peaks would result in a scheme with maximal conflicts (Varsani et al. 2014), it seems rational to propose a species demarcation threshold of $>72 \%$ genome-wide pairwise identity for grabloviruses. This threshold will need to be revisited as more Grablovirus sequences become available. In addition, this threshold should be considered along with one or more of other criteria such as (i) similarities in the genome organization of the putative member with existing grabloviruses, (ii) close phylogenetic relationship relative to members of other Geminiviridae genera (Fig. 3), (iii) similarity in number and arrangement of encoded genes (Fig. 2; Table 3), and (iv) high levels of CP- and Rep-associated protein nucleotide and amino acid identities (Table 3).

On the origin of grabloviruses, three hypotheses were proposed by Cieniewicz et al. (2017) for GRBV, its type species. The first postulated a global distribution for GRBV, with implications for its possible evolution from any of the viticultural regions of the world. The second proposed a North American origin for GRBV and its subsequent spread to other viticultural regions via movement of contaminated vegetative cuttings. In the third hypothesis, GRBV or its progenitor are thought to have originated from a yet-to-be-identified host from which it moved between hosts via possible arthropod 


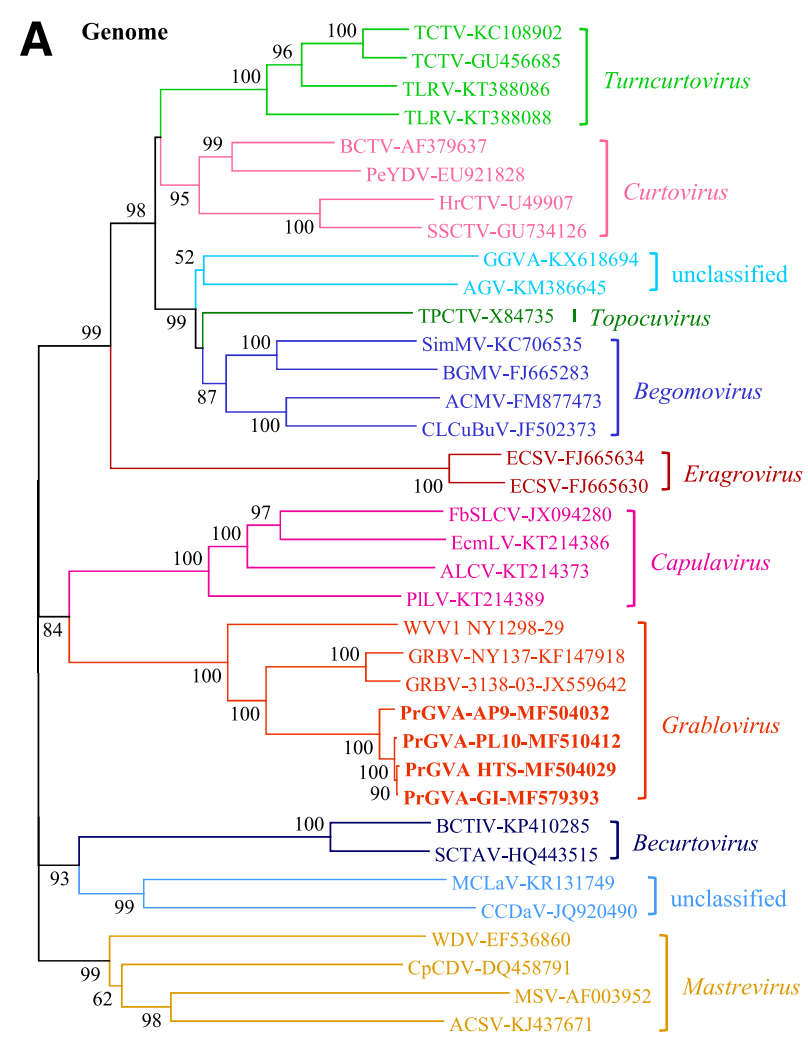

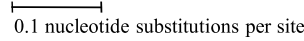
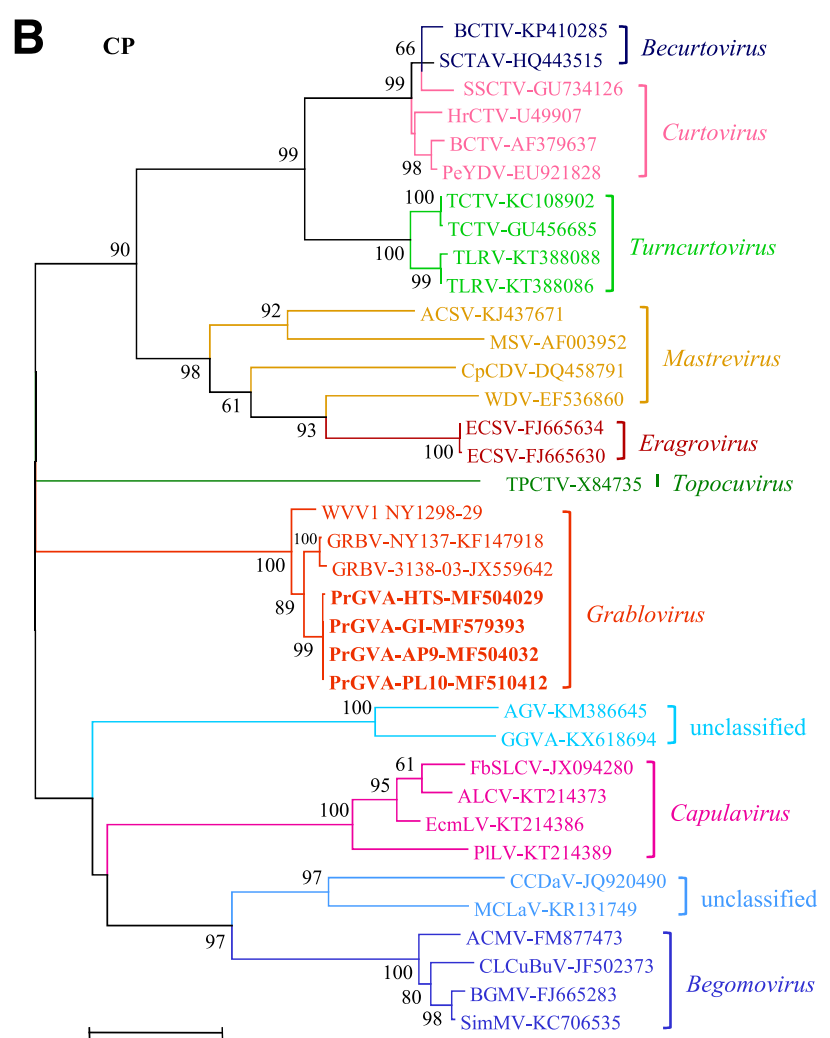

0.5 amino acids substitutions per site

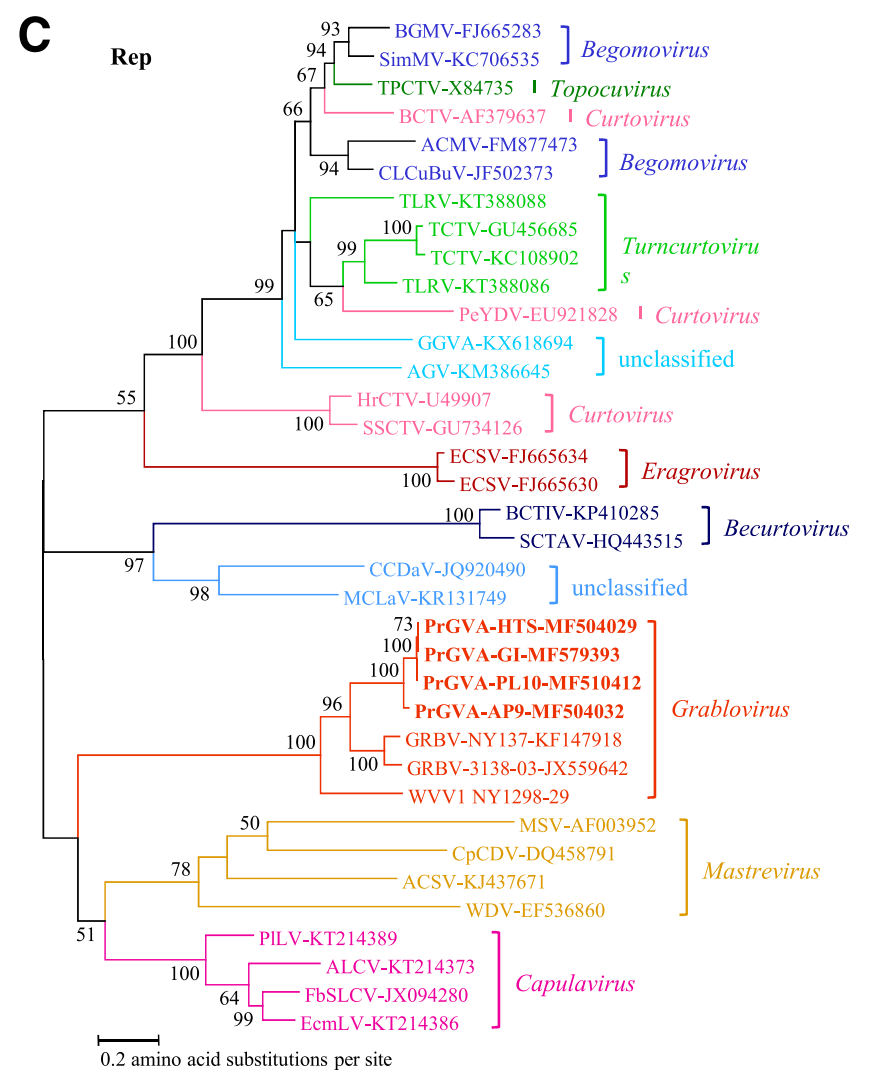

Fig. 3. Unrooted neighbor-joining phylogenetic trees reconstructed from the alignment of $\mathbf{A}$, the complete genome nucleotide sequences as well as $\mathbf{B}$, amino acid sequences of coat protein (CP) and C, rep-associated protein (Rep) of Prunus geminivirus A (PrGVA) and representative members of the family Geminiviridae. The trees were constructed using the MEGA7 program (Kumar et al. 2016) and percent bootstrap values (1,000 replicates) are indicated at the branch internodes. AGV = Apple geminivirus, BCTV $=B$ eet curly top virus, HrCTV = Horseradish curly top virus, SCTAV = Spinach curly top Arizona virus, BCTIV = Beet curly top Iran virus, TCTV = Turnip curly top virus, ECSV = Eragrostis curvula streak virus, WDV = Wheat $d$ warf virus, MSV = Maize streak virus, PanSV $=$ Panicum streak virus, TPCTV = Tomato pseudo-curly top virus, GRBV $=$ Grapevine red blotch virus, FbSLSV French bean severe leaf curl virus, $\mathrm{EcmLV}=$ Euphorbia caput-medusae latent virus, $\mathrm{GGVA}=$ grapevine geminivirus $\mathrm{A}, \mathrm{MMDaV}=$ Mulberry mosaic $d$ warf-associated virus, $\mathrm{CCDaV}=$ Citrus chlorotic dwarf-associated virus, TLCCNV = Tomato leaf curl China virus, ELCV = Euphorbia leaf curl virus, ToLCMGV = Tomato leaf curl Madagascar virus, EACMV = East African cassava mosaic virus, TYLCCNV = Tomato yellow leaf curl China virus, AYVV = Ageratum yellow vein virus, and ToLCHaV = Tomato leaf curl Hainan virus . 
vectors capable of feeding on these hosts. These hypotheses could readily be extended to the genus given the considerable relationship between GRBV, PrGVA, and WVV1. On the one hand, the combination of recent detection of the GRBV in free-living vines

Table 4. Prevalence and species distribution of Prunus geminivirus A (PrGVA) in the National Clonal Germplasm Repository collection, Winters, $\mathrm{CA}^{\mathrm{a}}$

\begin{tabular}{lccc}
\hline Crop, species & Number tested & Number infected & Positive (\%) \\
\hline Plum & & & \\
Prunus americana & 3 & 0 & 0.0 \\
P. bokhariensis & 3 & 2 & 66.7 \\
P. cerasifera & 2 & 1 & 50.0 \\
P. domestica & 20 & 11 & 55.0 \\
Prunus hybrid & 4 & 3 & 75.0 \\
P. maritima & 1 & 1 & 100.0 \\
P. munsoniana & 1 & 0 & 0.0 \\
P. salicina & 10 & 7 & 70.0 \\
P. simonii & 1 & 1 & 100.0 \\
Prunus spp. & 6 & 2 & 33.3 \\
P. spinosa & 1 & 1 & 100.0 \\
Apricot & & & \\
P. armeniaca & 42 & 32 & 76.2 \\
Prunus hybrid & 1 & 0 & 0.0 \\
P. mandshurica & 1 & 1 & 100.0 \\
P. mume & 5 & 1 & 20.0 \\
Cherry & & & \\
P. avium & 20 & 0 & 0.0 \\
P. cerasus & 10 & 2 & 20.0 \\
P. mahaleb & 1 & 0 & 0.0 \\
P. serotina & 1 & 0 & 0.0 \\
Prunus spp. & 1 & 0 & 0.0 \\
P. tomentosa & 1 & 1 & 100.0 \\
P. virginiana & 1 & 0 & 0.0 \\
Prunus $\times$ yedoensis & 1 & 0 & 0.0 \\
\hline . al 20 alm and & & & \\
\hline
\end{tabular}

${ }^{\mathrm{a}}$ In all, 20 almond and 58 peach trees were also screened for PrGVA but all tested negative for the virus. proximal to commercial grapevine red blotch disease-affected vineyards in California (Perry et al. 2016), the North American origin of all characterized GRBV isolates to date, and the characterization of WVV1 from noncultivated grapevine (Perry et al. 2018) would favor the second hypothesis. Moreover, the discovery of PrGVA and its identification in several exotic Prunus accessions sourced from countries outside North America would favor the first hypothesis. Regardless of the geographical origin of these viruses, the discovery of WVV1 (Perry et al. 2018) and PrGVA (this study) favors the argument of a plausible evolution of grabloviruses from non- $V$. vinifera hosts and subsequent host jump of these viruses into cultivated hosts enabled by polyphagous arthropod vectors. The future identification of insect vectors for WVV1 and PrGVA and further studies on the ecology of all three grabloviruses will shed more light on the evolutionary pathway of members of this genus.

Graft transmissibility is a key feature of plant viruses in establishing disease etiology (Rowhani et al. 2005). Transmission of PrGVA was verified by grafting chip buds of three diseased source vines on test plants of GF 305 maintained under greenhouse conditions.

Systemic movement of the virus into the leaves distal to the grafted sites was detected at 6 months after inoculation by PCR assays. However, the grafted plants did not show any visible virus symptoms, similar to the source FT7 plant. Given the relationship of PrGVA to GRBV, it will be interesting to investigate the response of grapevine to this novel Grablovirus sp. enabled by the development of infectious clones for PrGVA. Furthermore, the investigation of a potential vector for PrGVA will shed further light on salient aspects of its biology and epidemiology.

In conclusion, this study reports the detection and characterization of PrGVA, a graft-transmissible putative Grablovirus spp. infecting Prunus spp. This discovery also represents the first identification of a geminivirus from Prunus spp. From a practical standpoint, the qPCR assay developed in this study will be useful for investigating the incidence, spread, and epidemiology of PrGVA across Prunus orchards worldwide.

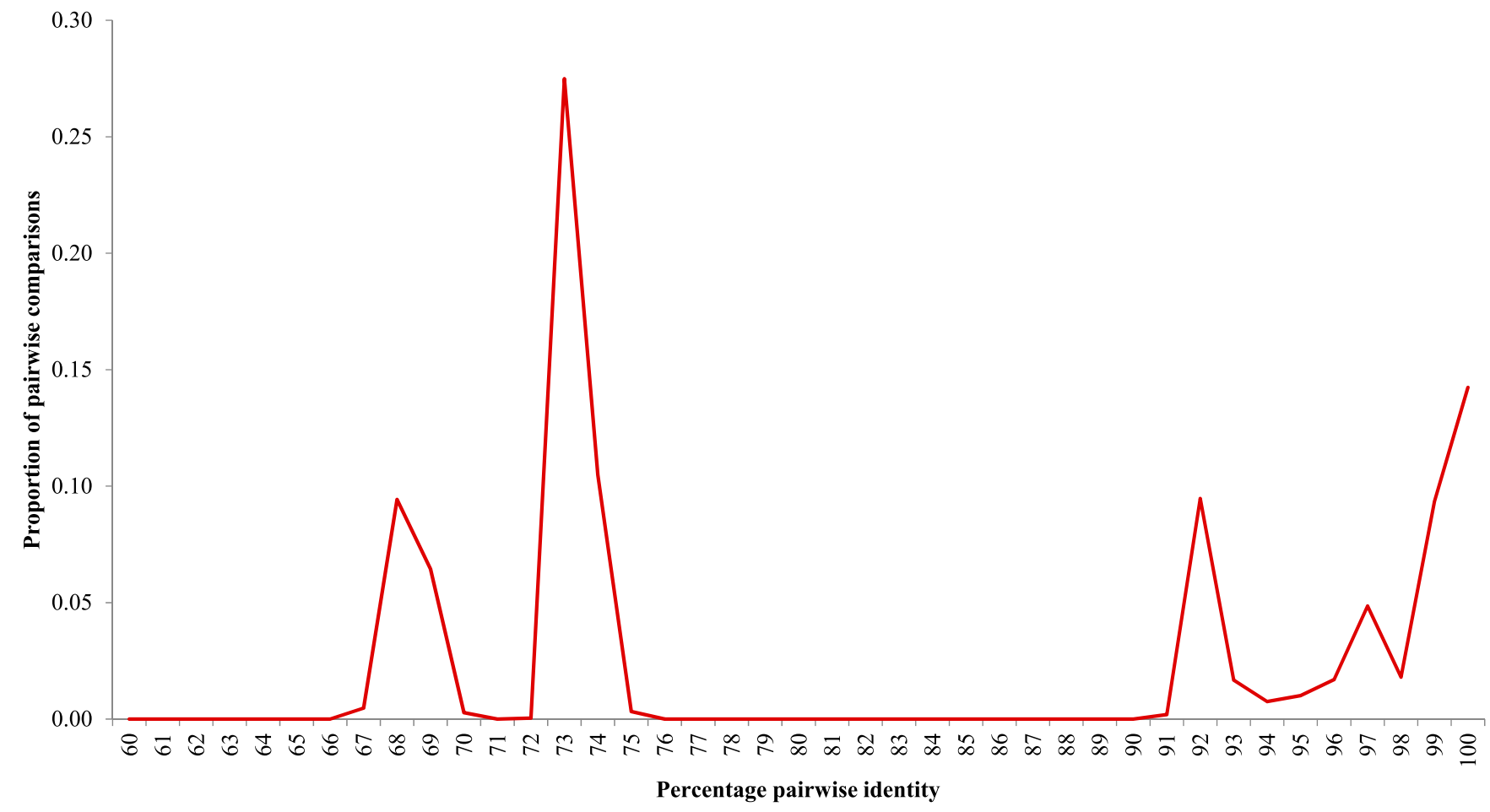

Fig. 4. Distribution of pairwise identities of comparisons among complete genome sequences of 81 isolates of three grabloviruses (Grapevine red blotch virus $=53$, Wild vitis virus $1=9$, and Prunus geminivirus $A=19$ ). Pairwise identities were calculated using SDT v1.2 (Muhire et al. 2014) with the MUSCLE-alignment option. Percent pairwise identities are indicated on the horizontal axis while the proportions of pairwise identities are shown on the vertical axis. According to Muhire et al. (2013), the valleys between peaks in the plot indicate percent pairwise identities that would make relatively conflict-free pairwise-identity-score-based taxonomic demarcation thresholds. 


\section{Acknowledgments}

We thank M. Hwang and J. M. Puckett, UC Davis Foundation Plant Services, for help with the biological indexing tests; L. Gregg from the Texas A\&M AgriLife Research for her technical assistance; C. Debuse from the United States Department of Agriculture NCGR for her help in providing a list of Prunus cultivars and the map of the orchard; and K. Farrar for critical reading of the manuscript.

\section{Literature Cited}

Adams, M. J., Lefkowitz, E. J., King, A. M., Harrach, B., Harrison, R. L., Knowles, N. J., Kropinski, A. M., Krupovic, M., Kuhn, J. H., Mushegian, A. R., Nibert, M., Sabanadzovic, S., Sanfaçon, H., Siddell, S. G., Simmonds, P., Varsani, A., Zerbini, F. M., Gorbalenya, A. E., and Davison, A. J. 2017. Changes to taxonomy and the International Code of Virus Classification and Nomenclature ratified by the International Committee on Taxonomy of Viruses (2017). Arch. Virol. 162: 2505-2538.

Al Rwahnih, M., Alabi, O. J., Westrick, N. M., Golino, D., and Rowhani, A. 2017. Description of a novel monopartite geminivirus and its defective subviral genome in grapevine. Phytopathology 107:240-251.

Al Rwahnih, M., Ashita, D., Anderson, M., Rowhani, A., Uyemoto, J. K., and Sudarshana, M. R. 2013. Association of a DNA virus with grapevines affected by red blotch disease in California. Phytopathology 103:1069-1076.

Al Rwahnih, M., Rowhani, A., and Golino, D. 2015. First report of Grapevine red blotch associated virus in archival grapevine material from Sonoma County, California. Plant Dis. 99:895.

Bahder, B. W., Zalom, F. G., Jayanth, M., and Sudarshana, M. R. 2016 a. Phylogeny of geminivirus coat protein sequences and digital PCR aid in identifying Spissistilus festinus as a vector of Grapevine red blotch-associated virus. Phytopathology 106:1223-1230.

Bahder, B. W., Zalom, F. G., and Sudarshana, M. R. 2016b. An evaluation of the flora adjacent to wine grape vineyards for the presence of alternative host plants of Grapevine red blotch-associated virus. Plant Dis. 100:1571-1574.

Bernardo, P., Golden, M., Akram, M., Nadarajan, N., Naimuddin, Fernandez E., Granier, M., Rebelo, A. G., Peterschmitt, M., Martin, D. P., and Roumagnac, P. 2013. Identification and characterisation of a highly divergent geminivirus: evolutionary and taxonomic implications. Virus Res. 177:35-45.

Bernardo, P., Muhire, B., Francois, S., Deshoux, M., Hartnady, P., Farkas, K., Kraberger, S., Filloux, D., Fernandez, E., Galzi, S., Ferdinand, R., Granier, M., Marais, A., Monge Blasco, P., Candresse, T., Escriu, F., Varsani, A., Harkins, G. W., Martin, D. P., and Roumagnac, P. 2016. Molecular characterization and prevalence of two capulaviruses: Alfalfa leaf curl virus from France and Euphorbia caputmedusae latent virus from South Africa. Virology 493:142-153.

Brameier, M., Krings, A., and MacCallum, R. M. 2007. NucPred-Predicting nuclear localization of proteins. Bioinformatics 23:1159-1160.

Brown, J. K., Zerbini, M., Navas-Castillo, J., Moriones, E., Ramos-Sobrinho, R., Silva, J. C. F., Fiallo-Olivé, E., Briddon, R. W., Hernández-Zepeda, C., Idris, A., Malathi, V. G., Martin, D. P., Rivera-Bustamante, R., Ueda, S., and Varsani, A. 2015. Revision of Begomovirus taxonomy based on pairwise sequence comparisons. Arch. Virol. 160:1593-1619.

Bustin, S. A., Benes, V., Garson, J. A., Hellemans, J., Huggett, J., Kubista, M., Mueller, R., Nolan, T., Pfaffl, M. W., Shipley, G. L., Vandesompele, J., and Wittwer, C. T. 2009. The MIQE guidelines: Minimum information for publication of quantitative real-time PCR experiments. Clin. Chem. 55:611-622.

Cieniewicz, E., Perry, K., and Fuchs, M. 2017. Grapevine red blotch: Molecular biology of the virus and management of the disease. Pages 303-314 in: Grapevine Viruses: Molecular Biology, Diagnostics and Management. B. Meng, G. P. Martelli, D. A. Golino, and M. Fuchs, eds. Springer International Publishing AG, Cham, Switzerland.

Fuchs, M. F., Krenz, B., Yepes, L. M., Thompson, J. R., McLane, H., and Perry, K. L. 2015. Is Grapevine red blotch-associated virus the causal agent of red blotch disease? Pages 72-73 in Proc. 18th Congr. Int. Counc. Study Virus Virus-like Dis. Grapevine. F. Ertunç, ed. Ankara, Turkey.

Hodgetts, J., Boonham, N., Mumford, R., and Dickinson, M. 2009. Panel of 23S rRNA gene-based real-time PCR assays for improved universal and groupspecific detection of phytoplasmas. Appl. Environ. Microbiol. 75:2945-2950.

Inoue-Nagata, A. K., Albuquerque, L. C., Rocha, W. B., and Nagata, T. 2004. A simple method for cloning the complete begomovirus genome using the bacteriophage phi29 DNA polymerase. J. Virol. Methods 116:209-211.

Jelkmann, W. 2004. International working group on fruit tree viruses. Acta Hortic. 657:575-596.
Krenz, B., Thompson, J. R., Fuchs, M., and Perry, K. L. 2012. Complete genome sequence of a new circular DNA virus from grapevine. J. Virol. 86:7715.

Kumar, S., Stecher, G., and Tamura, K. 2016. MEGA7: Molecular Evolutionary Genetics Analysis version 7.0 for bigger datasets. Mol. Biol. Evol. 33:1870-1874.

Liang, P., Navarro, B., Zhang, Z., Wang, H., Lu, M., Xiao, H., Wu, Q., Zhou, X., Di Serio, F., and Li, S. 2015. Identification and characterization of a novel geminivirus with monopartite genome infecting apple trees. J. Gen. Virol. 96: 2411-2420.

Loconsole, G., Saldarelli, P., Doddapaneni, H., Savino, V., Martelli, G. P., and Saponari, M. 2012. Identification of a single-stranded DNA virus associated with citrus chlorotic dwarf disease, a new member in the family Geminiviridae. Virology 432:162-172.

Ma, Y., Navarro, B., Zhang, Z., Lu, M., Zhou, X., Chi, S., Di Serio, F., and Li, S. 2015. Identification and molecular characterization of a novel monopartite geminivirus associated with mulberry mosaic dwarf disease. J. Gen. Virol. 96:2421-2434.

Muhire, B., Martin, D. P., Brown, J. K., Navas-Castillo, J., Moriones, E., Zerbini, F. M., Rivera-Bustamante, R., Malathi, V. G., Briddon, R. W., and Varsani, A. 2013. A genome-wide pairwise-identity-based proposal for the classification of viruses in the genus Mastrevirus (family Geminiviridae). Arch. Virol. 158: 1411-1424.

Muhire, B., Varsani, A., and Martin, D. P. 2014. SDT: A virus classification tool based on pairwise sequence alignment and identity calculation. PLoS One 9: e108277.

Nash, T. E., Dallas, M. B., Reyes, M. I., Buhrman, G. K., Ascencio-Ibanez, J. T., and Hanley-Bowdoin, L. 2011. Functional analysis of a novel motif conserved across geminivirus Rep proteins. J. Virol. 85:1182-1192.

Osman, F., Al Rwahnih, M., Golino, D., Pitman, T., Cordero, F., Preece, J. E., and Rowhani, A. 2012. Evaluation of the phytosanitary status of the Prunus species in the National Clonal Germplasm Repository in California: Survey of viruses and viroids. J. Plant Pathol. 94:249-253.

Perry, K. L., McLane, H., Hyder, M. Z., Dangl, G. S., Thompson, J. R., and Fuchs, M. F. 2016. Grapevine red blotch-associated virus is present in free-living Vitis sp. proximal to cultivated grapevines. Phytopathology 106:663-670.

Perry, K. L., McLane, H., Thompson, J. R., and Fuchs, M. 2018. A novel grablovirus from non-cultivated grapevine (Vitis sp.) in North America. Arch. Virol. 163:259-262.

Polston, J. E., Londono, M. A., and Capobianco, H. 2014. The complete genome sequence of New World jatropha mosaic virus. Arch. Virol. 159:3131-3136.

Poojari, S., Alabi, O. J., Fofanov, V. Y., and Naidu, R. A. 2013. A leafhoppertransmissible DNA virus with novel evolutionary lineage in the family Geminiviridae implicated in grapevine redleaf disease by next-generation sequencing. PLoS One 8:e64194.

Ricketts, K. D., Goomez, M. I., Atallah, S. S., Fuchs, M. F., Martinson, T. E., Battany, M. C., Bettiga, L. J., Cooper, M. L., Verdegaal, P. S., and Smith, R. J. 2015. Reducing the economic impact of grapevine leafroll disease in California: Identifying optimal disease management strategies. Am. J. Enol. Vitic. 66:138-147.

Roumagnac, P., Granier, M., Bernardo, P., Deshoux, M., Ferdinand, R., Galzi, S., Fernandez, E., Julian, C., Abt, I., Filloux, D., Mesleard, F., Varsani, A., Blanc, S., Martin, D. P., and Peterschmitt, M. 2015. Alfalfa leaf curl virus: An aphidtransmitted geminivirus. J. Virol. 89:9683-9688.

Rowhani, A., Uyemoto, J. K., Golino, D. A., and Martelli, G. P. 2005. Pathogen testing and certification of Vitis and Prunus species. Annu. Rev. Phytopathol. 43:261-278.

Solovyev, V. V. 2007. Statistical approaches in Eukaryotic gene prediction. Pages 97-159 in: Handbook of Statistical Genetics, 3d ed. D. J. Balding, M. Bishop, and C. Cannings, eds. Wiley-Interscience, Chichester, West Sussex, England.

Susi, H., Laine, A.-L., Filloux, D., Kraberger, S., Farkas, K., Bernardo, P., Frilander, M. J., Martin, D. P., Varsani, A., and Roumagnac, P. 2017. Genome sequences of a capulavirus infecting Plantago lanceolata in the Åland archipelago of Finland. Arch. Virol. 162:2041-2045.

Varsani, A., Navas-Castillo, J., Moriones, E., Hernandez-Zepeda, C., Idris, A., Brown, J. K., Zerbini, F. M., and Martin, D. P. 2014. Establishment of three new genera in the family Geminiviridae: Becurtovirus, Eragrovirus and Turncurtovirus. Arch. Virol. 159:2193-2203.

Varsani, A., Roumagnac, P., Fuchs, M., Navas-Castillo, J., Moriones, E., Idris, A., Briddon, R. W., Rivera-Bustamante, R., Zerbini, F. M., and Martin, D. P. 2017. Capulavirus and Grablovirus: Two new genera in the family Geminiviridae. Arch. Virol. 162:1819-1831. 